\title{
A comparison of licensed and un-licensed artisanal and small-scale gold miners (ASGM) in terms of socio-demographics, work profiles, and injury rates
}

\author{
Benedict N. L. Calys-Tagoe ${ }^{1 *}$, Edith Clarke ${ }^{2}$, Thomas Robins ${ }^{3}$ and Niladri Basu 3 3,4
}

\begin{abstract}
Background: Artisanal and small-scale gold mining (ASGM) represents one of the most hazardous work environments. While formalization of this sector has been suggested (e.g., Minamata Convention) as a means to improve working conditions, we are unaware of empirical evidence that supports this notion.

This study aimed to compare sociodemographic profiles, work profiles, and injury rates among miners working in licensed versus un-licensed ASGM sites.

Methods: In the Tarkwa mining region of Ghana, 404 small-scale miners were recruited in 2014 and interviewed regarding their occupational injury experiences over the preceding 10 years. Workers were drawn from 9 mining sites, of which 5 were licensed and 4 were not licensed.

Results: Sociodemographic characteristics of miners from the two groups were relatively similar. Those currently working in an un-licensed mine have spent more time in the ASGM sector than those currently working in a licensed mine (94 vs. 70 months). Miners working in an un-licensed site tended to experience more injury episodes (e.g., 26\% vs. $8 \%$ had 3 or more injury events) and not use personal protective equipment during the time of an injury (92\% indicated to not using vs. 73\%) when compared to miners working in a licensed site. A total of 121 injury episodes were recorded for 2245 person years of ASGM work. The injury rate for those working in un-licensed mines was 5.9 per 100 person years (59 injuries in 995 person years) versus 5.0 (62 injuries in 1250 person-years) in the licensed mines. When focusing on the male miners, there was a significant difference in injury rates between those working in a licensed mine (4.2 per 100 person years) versus an un-licensed mine (6.1 per 100 person years).
\end{abstract}

Conclusions: These findings advance our understanding of injuries amongst ASGM workers, and help identify important differences in socio-demographics, work profiles, and injury rates between miners working in a licensed versus and un-licensed site. The findings suggest that certain working conditions in a licensed site may be safer.

Keywords: Miners, Occupational health, Occupational injuries, Public health, Workplace, Vulnerable populations, Informal sector

\footnotetext{
* Correspondence: calys75@hotmail.com

${ }^{1}$ Department of Community Health, University of Ghana School of Public

Health, Accra, Ghana

Full list of author information is available at the end of the article
}

\section{$\int$ Biomed Central}

(c) The Author(s). 2017 Open Access This article is distributed under the terms of the Creative Commons Attribution 4.0 International License (http://creativecommons.org/licenses/by/4.0/), which permits unrestricted use, distribution, and reproduction in any medium, provided you give appropriate credit to the original author(s) and the source, provide a link to the Creative Commons license, and indicate if changes were made. The Creative Commons Public Domain Dedication waiver (http://creativecommons.org/publicdomain/zero/1.0/) applies to the data made available in this article, unless otherwise stated. 


\section{Background}

Over the past decade artisanal and small-scale gold mining (ASGM) has proliferated worldwide due to powerful economic forces. Upwards of 15 million people may directly be involved in ASGM with another 100 million people estimated to be reliant upon the sector $[1,2]$. Several health concerns exist in ASGM communities [3]. Much of the initial concern focused on human exposures to mercury as well as the poor health infrastructure within ASGM communities, although there is now greater awareness and evidence that a multitude of health hazards plague the ASGM sector including, for example, human exposures to many social stressors [4], toxic elements other than mercury [3], and noise pollution [5].

According to the Small-Scale Gold Mining law of Ghana (1989, PNDCL 218, section 21), small-scale (gold) mining is defined as "...mining (gold) by any method not involving substantial expenditure by an individual or group of persons not exceeding nine in number or by a co-operative society made up of ten or more persons". When this is done using rudimentary tools such as shovels and pick axes, it is referred to as artisanal mining. Artisanal and small-scale gold mining, like other forms of mining, represents one of the most hazardous work environments [6]. For the ASGM sector, there is limited research addressing occupational hazards, though it is widely observed that miners are regularly injured because of falls, being struck by objects, exposure to extreme temperatures, misuse of or faulty power tools and equipment, and lacerations, as well as tunnel collapses resulting from weak ore formations or inadequate trenching and shoring. Deaths and injuries have been reported from several sites across Latin America, Asia, and Africa [7-9]. Few ASGM miners use personal protective equipment $[10,11]$, though the empirical evidence base for this as well as the preceding statements is relatively weak.

As the ASGM sector grows worldwide there is a pressing need for occupational hazards and injury factors to be quantitatively and rigorously studied so that findings may inform actions to improve working conditions. Furthermore, within the international UN Minamata Convention on Mercury there exists special mention of the ASGM sector (i.e., Article 7 and Annex C), and in particular a requirement of countries with ASGM activities that are more than insignificant to develop and implement a national action plan that includes public health strategies to protect vulnerable populations. One way forward, as mentioned in several government, NGO [11], and academic publications [12-14], as well as the Minamata Convention (Annex C 1-c) is to take steps to formalize the ASGM sector. It is believed that informal mining poses even more hazards than what may be found in a highly organized and/or regulated and/or large-scale operation. For example, the International Labour Organization has estimated that non-fatal accidents may be 7 times more common in mining operations that are informal when compared to large-scale operations [11]. The formalization process in Ghana requires the acquisition of land, notification of the Minerals commission, environmental impact assessment, and the payment of stipulated fees. While it is believed that formalization of the sector will help improve working conditions within ASGM sites, we are not aware of any empirical support of this notion. With this in mind, the objective of the current study was to compare sociodemographic profiles, work profiles, and injury rates among miners working in licensed versus un-licensed ASGM sites. We addressed this objective through further analysis of data we had previously collected in a cross-sectional study conducted in the Tarkwa region of Ghana in which we characterized the socio-demographics of ASGM miners as well as their work activities and workrelated injuries [9].

\section{Methods}

A cross sectional survey was carried out in Ghana's Western Region between March and April of 2014 as previously detailed [9]. Briefly, 404 miners were recruited from 9 ASGM sites, 5 of which were licensed. The licensed mines were selected by simple random selection (from a list maintained by the district office of the Minerals Commission) of active mines that were licensed to operate within the study area. The unlicensed mines were identified using the concept of creating "contact zones". This concept is often used in the context of highly asymmetrical relations of domination and subordination, especially among people with unusual power relations. Small-scale miners in Ghana are looked upon as "threats" or "a menace" to the environment and society, and their activities are usually clamped down by the security agencies. These miners are therefore very suspicious and unwilling to cooperate with "strangers", including researchers, hence the use of this approach. The details are as elaborated by Calys-Tagoe et al. [9].

A structured, interviewer-administered questionnaire was used as previously described [9] to obtain information on socio-demographic characteristics, mining work history, and injuries. The injuries were categorized into mild ("no day lost" up to three days of absence from work), moderate (4-14 days of absence), and severe (absence for more than 14 days). The interviews were conducted by local trained medical staff proficient in English and Twi (the local dialect). The collected data was stored and analyzed electronically in SPSS (version 22), and double-keyed to ensure accuracy. Preliminary data analysis included tabulation of descriptive statistics 
for all measurements to understand the basic features of the dataset. Differences between licensed and unlicensed miners for key study variables were assessed using Chi-square and ANOVAs.

\section{Results}

\section{Socio-demographics}

A total of 404 ASGM workers from the Tarkwa mining district were interviewed (Table 1). These workers were drawn from 9 mining sites, of which 5 were licensed and 4 were not licensed. There were some variations in socio-demographic characteristics between the two groups. Notably, there were significantly more females sampled from the licensed sites; of the 32 females, only 2 worked in an un-licensed site. Nearly $75 \%$ of the miners were less than 40 years of age, with a mean age of 34 (range: $17-72$ years). Close to $30 \%$ of the miners had reported having completed senior high school, and nearly two-thirds reported to living currently with a partner; none of these varied significantly between miners working in a licensed versus un-licensed site. Self-reported tobacco use (not shown in Table 1) was minimal with only $3.5 \%$ who indicated that they currently smoked tobacco; almost $90 \%$ indicated to having never smoked tobacco. Among the $44 \%$ who reported drinking alcohol within the past 12 months, 60\% reported consuming an average of one drink per day. There were no significant differences in tobacco or alcohol use between licensed and un-licensed miners.

\section{Work profiles}

Participants self-reported to have worked in the ASGM sector from 1 month to 30 years, with a mean work duration of 76.3 months or 6.4 years (Table 1). Those currently working in an un-licensed mine had been working much longer in the ASGM sector than those currently working in a licensed mine ( 94 vs. 70 months or 7.8 versus 5.8 years on average). Further, $41 \%$ of miners currently employed in an un-licensed mine have worked in the ASGM sector for more than 10 years versus $22.4 \%$ of those currently employed in a licensed mine. The average number of years working at the individual's current mine was 4.2 , with the median number of years worked being 4 , and the 25th and 75th percentiles being 1.1 and 10 years, respectively. Two hundred and fifty two $(62.4 \%)$ of the miners had worked only at their current workplace (193 and 59 for licensed and unlicensed, respectively) throughout their mining career. Of the remaining 152 who have worked at two or more ASGM sites, 149 (98\%) had worked in both licensed and unlicensed sites.

All participants reported involvement in one or more of the 7 key ASGM activities we queried, namely excavation (49\%), crushing and grinding (46\%), sifting and shanking (13\%), washing and sluicing (39\%), amalgamation (33\%), burning (38\%), and carrying loads $(6 \%)$. More than $50 \%$ of the respondents indicated to being routinely involved in more than one activity, with $25 \%$ of them indicating to be involved in 4 or more activities on a regular basis. While there were no statistically significant differences between the licensed and un-licensed miners in terms of the number of work activities that they reported being currently involved with, the proportion of unlicensed miners involved in amalgamation (43\% vs. $29 \%$ ) and burning (54\% vs. $32 \%$ ) was higher than that for the licensed miners.

Table 1 Socio-demographic and work characteristics of the study population according to mine license status

\begin{tabular}{|c|c|c|c|c|c|c|c|c|c|c|c|c|c|c|}
\hline \multirow[t]{2}{*}{$\begin{array}{l}\text { Mine license } \\
\text { status }\end{array}$} & \multirow[t]{2}{*}{$\begin{array}{l}\text { Mine ID } \\
\text { number }\end{array}$} & \multirow[t]{2}{*}{$\begin{array}{l}\text { Sample } \\
\text { population }\end{array}$} & \multicolumn{3}{|c|}{ Age (years) } & \multirow[t]{2}{*}{ Male (\%) } & \multirow{2}{*}{$\begin{array}{l}\text { High } \\
\text { school } \\
\text { completed } \\
(\%)\end{array}$} & \multirow{2}{*}{$\begin{array}{l}\text { Living } \\
\text { with } \\
\text { partners } \\
(\%)\end{array}$} & \multicolumn{3}{|c|}{$\begin{array}{l}\text { Total \# months ever } \\
\text { worked in ASGM }\end{array}$} & \multicolumn{3}{|c|}{$\begin{array}{l}\text { Total \# months worked in } \\
\text { current ASGM site }\end{array}$} \\
\hline & & & Mean & SD & Range & & & & $\begin{array}{l}\text { Mean } \\
\text { (SD) }\end{array}$ & Median & Range & $\begin{array}{l}\text { Mean } \\
\text { (SD) }\end{array}$ & Median & Range \\
\hline \multirow{6}{*}{$\begin{array}{l}\text { Licensed } \\
\text { Mines }\end{array}$} & 1 & 33 & 34.1 & 13.4 & $17-72$ & 100 & 33.3 & 63.6 & $69(83)$ & 36 & $1-288$ & $47(59)$ & 24 & $1-240$ \\
\hline & 2 & 63 & 34.8 & 10.0 & $19-60$ & 79.4 & 22.2 & 58.7 & $66(75)$ & 36 & $1-360$ & $37(47)$ & 17 & $1-180$ \\
\hline & 3 & 65 & 37.2 & 11.4 & $20-65$ & 75.4 & 18.4 & 76.9 & $83(80)$ & 48 & $1-336$ & $54(58)$ & 36 & $1-240$ \\
\hline & 4 & 84 & 30.9 & 8.8 & $18-55$ & 100 & 23.8 & 63.1 & $67(70)$ & 51 & $1-360$ & $41(43)$ & 24 & $1-240$ \\
\hline & 5 & 49 & 33.7 & 11.5 & $19-66$ & 98 & 44.9 & 75.5 & $60(70)$ & 24 & $1-276$ & $48(58)$ & 24 & $1-180$ \\
\hline & Sub-Total & 295 & 34.0 & 10.8 & $17-72$ & 89.8 & 26.8 & 67.5 & $70(75)$ & 42 & $1-360$ & $45(53)$ & 24 & $1-240$ \\
\hline \multirow{5}{*}{$\begin{array}{l}\text { Un-licensed } \\
\text { Mines }\end{array}$} & 6 & 19 & 24.5 & 8.5 & $17-47$ & 100 & 31.6 & 26.4 & 49 (74) & 24 & $1-300$ & $24(32)$ & 12 & $1-132$ \\
\hline & 7 & 16 & 32.6 & 9.3 & $22-58$ & 100 & 43.8 & 37.5 & $70(54)$ & 48 & $4-168$ & $59(52)$ & 36 & $4-168$ \\
\hline & 8 & 19 & 34.0 & 10.4 & $17-54$ & 100 & 36.9 & 73.7 & $92(63)$ & 78 & $1-216$ & $52(59)$ & 24 & $1-180$ \\
\hline & 9 & 56 & 36.3 & 8.9 & $22-57$ & 96.4 & 28.6 & 76.7 & 119 (102) & 120 & $1-360$ & $83(95)$ & 24 & $1-288$ \\
\hline & Sub-Total & 109 & 33.2 & 10.0 & $17-58$ & 98.2 & 33.1 & 61.4 & 94 (89) & 60 & $1-360$ & $63(78)$ & 24 & $1-288$ \\
\hline Combined & & 404 & 33.8 & 10.6 & $17-72$ & 92.1 & 28.5 & 65.8 & $76(80)$ & 48 & $1-360$ & $50(61)$ & 24 & $1-288$ \\
\hline
\end{tabular}




\section{Injury rates}

Over the last 10 years (which is the time period for which participants were specifically queried about experiencing injuries from all their ASGM-related activities), the 404 study participants worked a total of 2245 person years in the ASGM sector (1250 years in licensed mines and 995 years in un-licensed mines). During this capture period, 95 of the 404 individuals interviewed reported at least one injury event that caused them to miss days of work or hampered their ability to work effectively when they showed up to work. The overall incidence proportion of injury was $23.5 \%$, with $17.3 \%$ for those working in a licensed mine and $40.3 \%$ for those working in an un-licensed mine. The majority of respondents who self-reported an injury event experienced a single injury (75/95). The number of miners experiencing 2, 3, 4, and 5 injuries over the 10-year period was 13, 5, 0, and 1, respectively, for a total of 121 injury episodes.

We further analyzed the injury events according to key variables (Table 2). Even though miners moved between licensed and unlicensed sites, our survey was designed to link a particular injury event with the mine's registration status at the time of injury. Miners working in an un-licensed site tended to experience more injury episodes (e.g., $26 \%$ vs. $8 \%$ had 3 or more injury events) and not use personal protective equipment during the time of an injury (92\% indicated to not using vs. $73 \%$ ) when compared to miners working in a licensed site. For other variables of interest (e.g., activity at the time of injury, time of day when the injury occurred, cause of injury, and severity of injury), there were no statistically significant differences between those working in a licensed versus un-licensed mine. However, some general observations warrant mention. First, the incidence of injury was most associated with two activities (excavation and crushing), which accounted for $82 \%$ of all injury-related events. Second, injuries tended to occur more often in the morning than during later parts of the day though we did not characterize frequency of activities throughout the entire work day. Third, the cause of injury in about two-third of all incidents was reported being struck by an object, though there were more diverse causes reported by miners from the un-licensed sites (e.g., fires, fall from height, and physical assault). Fourth, while a higher proportion of injuries amongst licensed miners were reported to be severe this was not to a level of statistical significance.

With a total of 121 injury episodes and 2245 person years of ASGM work, the overall injury rate was calculated at 5.39 per 100 person years (Table 3). The injury rate for those working in un-licensed mines was 5.93 per 100 person years (59 injuries in 995 person years) versus 4.96 (62 injuries in 1250 person-years) in the licensed mines resulting in a risk ratio of 1.2. Given that most women worked in a licensed site, and that we previously documented them to have a greater injury rate than men [9], we further sub-divided the analyses as outlined in Table 3. When focusing strictly on the male miners, the injury rate was significantly different between those working in a licensed mine (4.16 per 100 person years) versus an un-licensed mine (6.05 per 100 person years). Similar analyses were performed by strictly looking at injury events classified as severe (i.e., work absence for more than 14 days), and this mainly revealed that the rate of such events were more common in licensed mines (Table 4).

We also explored the injury rates for two variables from Table 2 that were statistically significant, namely number of injury episodes and work experience. The injury rates were not different between unlicensed and licensed miners who experienced 1 injury event (14.35/100 yrs. vs. 18.91/ 100 yrs., respectively; $p=0.11$ ) or 2 or more events (34.62/100 yrs. vs. 43.59/100 yrs., respectively; $p=0.23$ ). Injury rates varied according to work experience in both the unlicensed and licensed miners with rates being significantly higher in the less experienced miners (Table 5). Furthermore, among the miners with more than 5 years of work experience, the injury rates were more than $50 \%$ higher in the unlicensed group.

\section{Discussion}

There is growing concern worldwide about the ASGM sector, and in particular the occupational health risks faced by ASGM workers. One strategy forward, as articulated in academic papers [12-14] as well as in the UN Minamata Convention (Annex C 1-c), is to take steps to formalize the sector. For example, a polling exercise that involved diverse ASGM stakeholders and experts from across Ghanaian institutions revealed that the promotion of conditions to help ASGM miners register, regularize, and develop their mining activities consistently scored amongst the most preferred option for improving the health, environmental, and socioeconomic problems faced by ASGM communities [13]. While there are widely held beliefs and anecdotes that unlicensed mining poses more occupational hazards than what may be found in a regulated or large-scale operation [11], to our knowledge there has been no empirical evidence generated in support of this notion. We believe the current study is the first to scientifically compare a group of licensed and un-licensed ASGM mine workers. In doing so, we are able to compare the groups in terms of their socio-demographics, ASGM work profiles, and injury rates.

In Ghana, like other countries, those who engage in illegal ASGM activities are often vilified in the media and by governments [15] leading towards a simple perception that these two groups are different. In the 
Table 2 Attributes of self-reported injury related events comparing those working in a licensed versus un-licensed ASGM site

\begin{tabular}{|c|c|c|c|c|}
\hline Injury-related events & $\begin{array}{l}\text { Licensed } \\
(N=62) \%\end{array}$ & $\begin{array}{l}\text { Unlicensed } \\
(N=59) \%\end{array}$ & $\begin{array}{l}\text { All sites } \\
(N=121) \%\end{array}$ & $\begin{array}{l}p- \\
\text { value }\end{array}$ \\
\hline \multicolumn{5}{|c|}{ Activity at the time of injury } \\
\hline Excavation & 55 & 63 & 59 & \multirow[t]{5}{*}{0.16} \\
\hline Crushing & 23 & 24 & 23 & \\
\hline Washing/sluicing & 3 & 0 & 2 & \\
\hline Burning & 0 & 3 & 2 & \\
\hline $\begin{array}{l}\text { Movement between } \\
\text { locations }\end{array}$ & 19 & 9 & 14 & \\
\hline \multicolumn{5}{|c|}{ Time of day injury occurred } \\
\hline Morning & 44 & 44 & 44 & \multirow[t]{3}{*}{0.79} \\
\hline Afternoon & 39 & 34 & 36 & \\
\hline Evening/night & 18 & 22 & 20 & \\
\hline \multicolumn{5}{|l|}{ Cause of injury } \\
\hline Struck by an object & 76 & 58 & 67 & \multirow[t]{7}{*}{0.10} \\
\hline Machinery/tool & 11 & 15 & 13 & \\
\hline Fire/flames/heat & 0 & 3 & 2 & \\
\hline Fall from a height & 0 & 7 & 3 & \\
\hline Fall on level ground & 5 & 0 & 3 & \\
\hline Physical assault & 0 & 3 & 2 & \\
\hline Other & 5 & 9 & 7 & \\
\hline \multicolumn{5}{|l|}{ Severity of injury } \\
\hline Mild & 32 & 29 & 31 & \multirow[t]{3}{*}{0.20} \\
\hline Moderate & 40 & 29 & 35 & \\
\hline Severe & 27 & 42 & 35 & \\
\hline \multicolumn{5}{|c|}{$\begin{array}{l}\text { Number of injury episodes } \\
\text { experienced by individual miners }\end{array}$} \\
\hline 1 & 71 & 56 & 64 & \multirow[t]{5}{*}{0.04} \\
\hline 2 & 21 & 19 & 20 & \\
\hline 3 & 8 & 17 & 12 & \\
\hline 4 & 0 & 0 & 0 & \\
\hline 5 & 0 & 9 & 4 & \\
\hline \multicolumn{5}{|c|}{ Work experience (in years) } \\
\hline $0-5$ & 52 & 37 & 45 & \multirow[t]{5}{*}{0.02} \\
\hline $6-10$ & 26 & 20 & 23 & \\
\hline $11-15$ & 5 & 19 & 12 & \\
\hline $16-20$ & 10 & 22 & 16 & \\
\hline$>20$ & 8 & 2 & 5 & \\
\hline \multicolumn{5}{|l|}{ Training } \\
\hline Yes & 34 & 24 & 29 & \multirow[t]{2}{*}{0.22} \\
\hline No & 66 & 76 & 71 & \\
\hline \multicolumn{5}{|c|}{ Use of PPE at the time of injury } \\
\hline Yes & 27 & 9 & 18 & \multirow[t]{2}{*}{0.009} \\
\hline No & 73 & 92 & 82 & \\
\hline
\end{tabular}

Values in the cells represent column percentages. Significance was tested using chi-squared tests. $N=$ sample size (bold numbers) current study we found no striking socio-demographic differences (e.g., age, education level, living status, alcohol and cigarette consumption) between the miners currently working in a licensed and un-licensed site. Moreover, the fact that $98 \%$ of those miners who have worked at more than one site, have worked in both licensed and un-licensed sites at some point in time suggests that, at least in Ghana, there are not substantial or consistent differences with respect to the types (socioeconomic backgrounds, etc.) of individuals who may be found working in licensed vs. unlicensed mines. This also suggests that differences between licensed and unlicensed miners in terms of work-related safety (e.g., acute injuries) is most likely due to the differences in levels and types of hazards faced in the different types of mines, rather than any preexisting socioeconomic differences in the individuals employed (one exception from our work was related to work experience, and is discussed below). While there was a significant difference in terms of the number of females employed, this may likely not a true representation of the overall situation owing to the relatively small sample size. Here, only two women were sampled from the un-licensed ASGM sites and they reported zero injuries. The overall injury rate for females (11.9 injuries per 100 person years) is much greater than that of the men, and something that we previously discussed [9]. The role of females within the ASGM sector is important, discussed elsewhere by us and others $[1,16,17]$, and warrants much more attention.

There is some difficulty in generalizing whether an ASGM miner exclusively operates in an illegal manner, and this represents an important limitation of the current study (and likely also other studies concerning ASGM). In the current study, 65 and $54 \%$ of miners working in a licensed and unlicensed site currently had worked only in that current site throughout their mining career. Of the remaining miners who have worked at two or more ASGM sites, 98\% indicated to have worked in both licensed and unlicensed sites. As such, there is a tendency of many miners to move between licensed and unlicensed operations. In conversations we had with many study participants, they indicated being motivated mostly by financial gains and that they did not discriminate between the various mining sites based on their registration status, but rather on which of them had the ability to meet their financial demands. It should also be noted that ASGM miners in Ghana themselves are not licensed but rather the site in which they are operating.

Further comparisons of work characteristics between ASGM miners working in a licensed and unlicensed operation were revealing. Those who currently work in an un-licensed mine have been working longer in the ASGM sector. In terms of specific ASGM activities we queried (key ones being excavation, crushing and grinding, 
Table 3 A comparison of injury rates between sexes and mine licensing status

\begin{tabular}{|c|c|c|c|c|c|}
\hline & Overall injury rate & Injury rates at unlicensed sites & Injury rates at licensed sites & Rate ratio $(95 \% \mathrm{Cl})$ & $P$-value \\
\hline Both sexes & $\begin{array}{l}121 \text { injuries / } \\
2245 \text { person years } \\
=5.39 \text { injuries/100 person years }\end{array}$ & $\begin{array}{l}59 \text { injuries / } \\
995 \text { person years } \\
=5.93 \text { injuries/100 person years }\end{array}$ & $\begin{array}{l}62 \text { injuries / } \\
1250 \text { person years } \\
=4.96 \text { injuries/100 person years }\end{array}$ & $1.20(0.83-1.71)$ & 0.33 \\
\hline Males & $\begin{array}{l}107 \text { injuries / } \\
2128 \text { person years } \\
=5.03 \text { injuries/100 person years }\end{array}$ & $\begin{array}{l}59 \text { injuries / } \\
975 \text { person years } \\
=6.05 \text { injuries/100 person years }\end{array}$ & $\begin{array}{l}48 \text { injuries / } \\
1153 \text { person years } \\
=4.16 \text { injuries/100 person years }\end{array}$ & $1.45(0.99-2.14)$ & 0.05 \\
\hline Females & $\begin{array}{l}14 \text { injuries / } \\
117 \text { person years } \\
=11.97 \text { injuries } / 100 \text { person years }\end{array}$ & $\begin{array}{l}0 \text { injuries / } \\
20 \text { person years } \\
=0 \text { injuries/100 person years }\end{array}$ & $\begin{array}{l}14 \text { injuries / } \\
97 \text { person years } \\
=14.43 \text { injuries } / 100 \text { person years }\end{array}$ & / & $<0.01$ \\
\hline Rate Ratio & $0.42(0.25-0.76)$ & / & $0.29(0.16-0.54)$ & & \\
\hline$P$-value & $<0.01$ & 0.30 & $<0.01$ & & \\
\hline
\end{tabular}

The $p$-values refer to rate comparisons within a particular column or row, and for the rate ratio the $95 \%$ confidence interval is provided in the brackets

sifting and shanking, washing and sluicing, amalgamation, burning, and carrying loads) we found no difference between the groups. More than half of the respondents in each group indicated to being routinely involved in more than one activity. Although of potential interest, the proportion of un-licensed miners involved in amalgamation and burning was higher than the licensed miners. This could bode problems, in particular, for mercury exposure which others have shown to be largely due to burning activities [10]. Even though few miners are involved in burning mercury, the released chemical contaminates the entire worksite and broader community thus rendering everyone potentially exposed.

One of the key findings of the current study was the difference between the licensed and un-licensed miners with respect to their injury rates. The incidence proportion of injury was $17.3 \%$ for those working in a licensed mine versus $40.3 \%$ for those working in an un-licensed mine. Focusing strictly on the male miners, the injury rate among un-licensed miners (6.1 injuries per 100 person years) was significantly higher than licensed miners (4.2 injuries per 100 person years). In addition, among the miners with more than 5 years of work experience, the injury rates were more than $50 \%$ higher in the unlicensed group (5.2 injuries per 100 person years) than the licensed group (3.4 injuries per 100 person years). Comparing these values to other studies has proven challenging owing to the lack of information available. We are unaware of any studies comparing injury profiles (or other occupational and health measures) between licensed and unlicensed miners. Existing occupational health studies concerning ASGM are quite limited; they are largely descriptive, and vary greatly in methodology making it difficult to generalize and make comparisons. For example a previous study of small-scale miners in the Democratic Republic of the Congo [18] calculated an injury rate of 392 accidents per 100 person years though methodological differences (e.g., their sampling frame was one year and extended beyond ASGM) make it difficult to properly compare.

In addition to the injury rate we found that miners working in an un-licensed site tended to experience more injury episodes when compared to miners working in a licensed site though when stratified (1 injury event versus 2 or more) and normalized for personyears, we calculated no significant differences. The miners working in an un-licensed site also reported using less personal protective equipment during the time of the injury. A study from Ghana's north found that the majority of ASGM miners do not use personal protective equipment including items such

Table 4 A comparison of injury rates deemed to be 'severe' between sexes and mine licensing status

\begin{tabular}{|c|c|c|c|c|c|}
\hline & $\begin{array}{l}\text { Overall injury rates } \\
\text { deemed "severe" }\end{array}$ & $\begin{array}{l}\text { Severe injury rates at } \\
\text { unlicensed sites }\end{array}$ & $\begin{array}{l}\text { Severe injury rates at } \\
\text { licensed sites }\end{array}$ & Rate ratio $(95 \% \mathrm{Cl})$ & $P$-value \\
\hline Both sexes & $\begin{array}{l}42 \text { injuries / } \\
2245 \text { person years } \\
=1.9 \text { injuries/100 person years }\end{array}$ & $\begin{array}{l}14 \text { injuries / } \\
995 \text { person years } \\
=1.4 \text { injuries/100 person years }\end{array}$ & $\begin{array}{l}28 \text { injuries / } \\
1250 \text { person years } \\
=2.2 \text { injuries/100 person years }\end{array}$ & $0.64(0.32-1.18)$ & 0.15 \\
\hline Males & $\begin{array}{l}41 \text { injuries / } \\
2128 \text { person years } \\
=1.9 \text { injuries/100 person years }\end{array}$ & $\begin{array}{l}14 \text { injuries / } \\
975 \text { person years } \\
=1.4 \text { injuries/100 person years }\end{array}$ & $\begin{array}{l}27 \text { injuries / } \\
1153 \text { person years } \\
=2.3 \text { injuries/100 person years }\end{array}$ & $0.61(0.31-1.16)$ & 0.14 \\
\hline Females & $\begin{array}{l}1 \text { injuries / } \\
117 \text { person years } \\
=0.9 \text { injuries } / 100 \text { person years }\end{array}$ & $\begin{array}{l}0 \text { injuries / } \\
20 \text { person years } \\
=0 \text { injuries/ } 100 \text { person years }\end{array}$ & $\begin{array}{l}1 \text { injuries / } \\
97 \text { person years } \\
=1.0 \text { injuries/100 person years }\end{array}$ & / & 0.82 \\
\hline Rate Ratio & & / & $2.3(0.43-47)$ & & \\
\hline$P$-value & & 0.75 & 0.45 & & \\
\hline
\end{tabular}

The $p$-values refer to rate comparisons within a particular column or row, and for the rate ratio the $95 \%$ confidence interval is provided in the brackets 
Table 5 A comparison of injury rates between mine licensing status and the work experience of the miners

\begin{tabular}{|c|c|c|c|c|c|}
\hline & Overall injury rate & $\begin{array}{l}\text { Injury rates at } \\
\text { unlicensed sites }\end{array}$ & $\begin{array}{l}\text { Injury rates at } \\
\text { licensed sites }\end{array}$ & $\begin{array}{l}\text { Rate ratio } \\
(95 \% \mathrm{Cl})\end{array}$ & $P$-value \\
\hline Both Groups & $\begin{array}{l}121 \text { injuries / } \\
2245 \text { person years } \\
=5.39 \text { injuries } / 100 \text { person years }\end{array}$ & $\begin{array}{l}59 \text { injuries / } \\
995 \text { person years } \\
=5.93 \text { injuries } / 100 \text { person years }\end{array}$ & $\begin{array}{l}62 \text { injuries / } \\
1250 \text { person years } \\
=4.96 \text { injuries } / 100 \text { person years }\end{array}$ & $1.20(0.83-1.71)$ & 0.33 \\
\hline $\begin{array}{l}5 \text { years and less of } \\
\text { ASGM work experience }\end{array}$ & $\begin{array}{l}54 \text { injuries / } \\
659 \text { person years } \\
=8.19 \text { injuries } / 100 \text { person years }\end{array}$ & $\begin{array}{l}20 \text { injuries / } \\
245 \text { person years } \\
=8.16 \text { injuries } / 100 \text { person years }\end{array}$ & $\begin{array}{l}34 \text { injuries / } \\
414 \text { person years } \\
=8.21 \text { injuries/100 person years }\end{array}$ & $0.99(0.57-1.73)$ & 0.99 \\
\hline $\begin{array}{l}\text { More than } 5 \text { years of } \\
\text { ASGM work experience }\end{array}$ & $\begin{array}{l}67 \text { injuries / } \\
1586 \text { person years } \\
=4.22 \text { injuries } / 100 \text { person years }\end{array}$ & $\begin{array}{l}39 \text { injuries / } \\
750 \text { person years } \\
=5.20 \text { injuries } / 100 \text { person years }\end{array}$ & $\begin{array}{l}28 \text { injuries / } \\
836 \text { person years } \\
=3.35 \text { injuries/100 person years }\end{array}$ & $1.53(0.96-2.52)$ & 0.03 \\
\hline Rate Ratio & $1.94(1.36-2.78)$ & $1.57(0.92-2.69)$ & $2.45(1.49-4.04)$ & & \\
\hline$P$-value & $<0.001$ & 0.05 & $<0.001$ & & \\
\hline
\end{tabular}

The $p$-values refer to rate comparisons within a particular column or row, and for the rate ratio the $95 \%$ confidence interval is provided in the brackets

as hardhats, gloves, and steel toed boots [10]. Here we extend upon this study and report that the use of personal protective equipment may be less for those working in an un-licensed operation. Though, a limitation with our work is that we only queried about the use of personal protective equipment when an injury was self-reported, and so we do not have data on all the 404 miners that we engaged with. This would be an important area of future inquiry.

This study has several strengths. Foremost, to our knowledge it is the first epidemiological study to compare variables between miners who work in licensed and un-licensed ASGM sites. The sample size is relatively robust when compared to other ASGM studies, and the sampling strategy involving multiple sites was aimed at reducing bias. Nonetheless there are important limitations of our study that warrant mention. Recall bias is an inherent limitation in this type of study even though we utilized validated survey instruments and employed trained field staff, and also do not feel that those working in an un-licensed mine would recall past events differently than those working in a licensed mine. The sampling design was aimed at recruiting workers from both licensed and unlicensed sites. While it has been estimated that upwards of $85 \%$ of Ghana's ASGM workers do not have licenses [19], we were unable to properly enumerate this in the study region though we have no reason to believe that the selected mines were atypical.

\section{Conclusion}

In conclusion, these findings advance our understanding of injuries amongst ASGM workers, and help identify important differences in socio-demographics, work profiles, and injury rates between miners working in a licensed versus and un-licensed site. Such findings are important given that a number of authorities, including Annex C 1-c of the UN Minamata Convention, indicate formalization to be a potential solution to helping improve the health, environmental, and socioeconomic problems faced by ASGM communities though to our knowledge there has been no empirical evidence in support of this notion and thus our study fills an important knowledge gap.

\section{Acknowledgments}

The authors wish to thank the Management and staff of the Ghana Minerals Commission, especially Mr. Bernard Ntibery and Mr. Dickson, for their immense support in the identification and recruitment of the miners. We also wish to express our profound gratitude to the leaders of the small-scale miners association in the Tarkwa mining district of the Western region of Ghana for their immeasurable support. We are also indebted to all the smallscale miners who consented to be part of this study.

\section{Funding}

This research was supported by the Fogarty International Center of the U.S. National Institutes of Health under award number 1D43TW009353. The content is solely the responsibility of the authors and does not necessarily represent the official views of the U.S. National Institutes of Health.

\section{Availability of data and materials}

The datasets and materials used during the current study are available from the corresponding author upon reasonable request.

\section{Authors' contributions}

BNLCT contributed to the study design, analysis of data, writing and reviewing of manuscript and coordinated the data collection process. EC contributed to the study design and manuscript writing. TR contributed to the study design, data analysis and writing of the manuscript. NB contributed to the study design, data analysis as well as writing and reviewing of the manuscript. All authors have read and approved the final manuscript.

Ethics approval and consent to participate

Ethical approval for the study was obtained from the Ethics Review Committee of the Ghana Health Service (GHS) (ID NO: GHS-ERC: 17/03/14) and the Institutional Review Board (IRB) of the University of Michigan (ID NO: HUM00085165). Written informed consent was also obtained from each study participant.

Consent for publication

Not applicable.

Competing interests

The authors declare that they have no competing interests. 


\section{Publisher's Note}

Springer Nature remains neutral with regard to jurisdictional claims in published maps and institutional affiliations.

\section{Author details}

${ }^{1}$ Department of Community Health, University of Ghana School of Public Health, Accra, Ghana. ${ }^{2}$ Occupational and Environmental Health Unit, Ghana Health Service, Accra, Ghana. ${ }^{3}$ Department of Environmental Health Sciences, University of Michigan School Of Public Health, Ann Arbor, Ml 48109, USA.

${ }^{4}$ Faculty of Agricultural and Environmental Sciences, McGill University,

Montreal, QC H9X 3V9, Canada.

Received: 16 August 2016 Accepted: 25 October 2017

Published online: 06 November 2017

\section{References}

1. World Health Organization. Environmental and occupational health hazards associated with artisanal and small-scale gold mining. Geneva: WHO Document Production Services; 2016.

2. United Nations Environment Programme. 2012. Reducing Mercury Use in Artisanal and Small-Scale Gold Mining: A Practical Guide. Available at: http:// www.unep.org/hazardoussubstances/Portals/9/Mercury/Documents/ASGM/ Tec hdoc/UNEP\%20Tech\%20Doc\%20APRIL\%202012_120608b_web.pdf. [Last accessed 3 Aug 2016].

3. Basu N, Clarke E, Green A, Calys-Tagoe B, Chan L, Dzodzomenyo M, Fobil J, Long R, Quansah R, Neitzel RL, Obiri S, Odei E, Ovadje L, Rajaee M, Wilson ML. Integrated assessment of artisanal and small-scale gold mining in Ghana - part 1: human health review. Int J Environ Res Public Health. 2015; 12(5):5143-7.

4. Wilson ML, Renne E, Roncoli C, Agyei-Baffour P, Tenkorang EY. Integrated assessment of artisanal and small-scale gold mining in Ghana - part 3: social sciences and economics. Int J Environ Res Public Health. 2015;12(7):8133-56.

5. Green A, Jones AD, Sun $K$, Neitzel RL. The association between noise, Cortisol and heart rate in a small-scale gold mining community-a pilot study. Int J Environ Res Public Health. 2015;12(8):9952-66.

6. International Labor Organization. 2010. Mining: a hazardous work. International Labor Organization: Geneva. Available online: http://www.lo. org/safework/areasofwork/hazardous-work/WCMS_124598/lang\%2D-en/ index.htm. [Last accessed 2 Aug 2016].

7. Kitula AGN. The environmental and socio-economic impacts of mining on local livelihoods in Tanzania: a case study of Geita District. J Clean Prod. 2006; 14:405-14

8. Hollaway J. The button gold mine, Zimbabwe. In: Jennings NS, editor. Small-scale gold mining: examples from Bolivia, Philippines \& Zimbabwe. Geneva: International Labour Organization; 1998.

9. Calys-Tagoe B, Ovadje L, Clarke E, Basu N, Robins T. Injury profiles associated with artisanal and small-scale gold mining in Tarkwa, Ghana. Int J Environ Res Public Health. 2015;12(7):7922-37.

10. Paruchuri Y, Siuniak A, Johnson N, Levin E, Mitchell K, Goodrich JM, Renne EP, Basu N. Occupational and environmental mercury exposure among small-scale gold miners in the Talensi-Nabdam District of Ghana's upper east region. Sci Total Environ. 2010;408:6079-85.

11. International Labour Organization. Social and labour issues in small-scale mines. In: Report for discussion at the tripartite meeting on social and labour issues in small-scale mines. Geneva: International Labour Organization; 1999.

12. Siegel S, Veiga M. Artisanal and small-scale mining as an extralegal economy: De Soto and the redefinition of "formalization". Resour Policy. 2009;34:51-6.

13. Basu A, Phipps S, Long R, Essegbey GO, Basu N. Identification of response options to artisanal and small-scale gold mining (ASGM) in Ghana via the Delphi process. Int J Environ Res Public Health. 2015;12(9):1345-11363.

14. Hinton JJ, Veiga MM, Veiga ATC. Clean artisanal gold mining: a utopian approach? J Clean Prod. 2003;11:99-115.

15. Banchirigah SM. Challenges with eradicating illegal mining in Ghana: a perspective from the grassroots. Resour Policy. 2008;33:29-38.

16. Long RN, Renne EP, Basu N. Understanding the social context of the ASGM sector in Ghana: a qualitative description of the demographic, health, and nutritional characteristics of a small-scale gold Mining Community in Ghana. Int J Environ Res Public Health. 2015;12(10):12679-96.
17. Hinton JJ, Veiga MM, Beinhoff C. Women and artisanal mining: gender roles and the road ahead. The Socio-economic impact of Artisanal and Small scale mining in Developing countries Ed. G Hilson, Pub. A.A.Balkema, Swets Publishers, Netherlands; 2003.

18. Elenge M, Leveque A, De Brouwer C. Occupational accidents in artisanal mining in Katanga, DRC. Int J Occup Med Environ Health. 2013;26:265-74.

19. Hilson G, Potter C. Why is illegal gold mining so ubiquitous in rural Ghana? Afr Dev Rev. 2003;15:237-70.

\section{Submit your next manuscript to BioMed Central and we will help you at every step:}

- We accept pre-submission inquiries

- Our selector tool helps you to find the most relevant journal

- We provide round the clock customer support

- Convenient online submission

- Thorough peer review

- Inclusion in PubMed and all major indexing services

- Maximum visibility for your research

Submit your manuscript at www.biomedcentral.com/submit
Biomed Central 